\title{
Producer profiles, production characteristics and mastitis control applications at dairy herds in Konya, Burdur and Kırklareli provinces, Turkey"
}

\author{
Cengiz YALÇIN ${ }^{1}$, Ahmet Şener YILDIZ ${ }^{1}$, Savaş SARIÖZKAN ${ }^{2}$, Aytekin GÜNLÜ ${ }^{3}$ \\ ${ }^{1}$ Department of Animal Health Economics and Management, Faculty of Veterinary Medicine, Ankara University, Ankara; \\ ${ }^{2}$ Department of Animal Health Economics and Management, Faculty of Veterinary Medicine, Erciyes University, Kayseri; \\ ${ }^{3}$ Department of Livestock Economics and Management, Faculty of Veterinary Medicine, Selçuk University, Konya-Turkey.
}

\begin{abstract}
Summary: In order to investigate the producer \& production characteristics and disease control applications at Turkish dairy herds, an interview survey was carried out in randomly selected 91 dairy herds out of 1684 Turkish Dairy Breeding Association herds in Burdur, Kurklareli and Konya provinces in July 2004. The study depicted that percentages of producers having education level higher than primary school, and not having any job training relate to dairy farming were $21 \%$ and $79 \%$ respectively. The majority of the producers did not follow innovations (46\%) and, was not aware of somatic cell counts and subclinical mastitis (93-97\%), and the European Union's regulations related to dairy farming (76\%). Amongst the producers interviewed, $13 \%$ used antiseptic when cleaning udder and $37 \%$ dried udder after washing. The percentage of producers using post milking teat dip, dry cow therapy, vaccination against mastitis, California Mastitis Test (CMT), and regularly keeping records for clinical cases were $18 \%, 62 \%, 29 \%$, $15 \%$ and $20 \%$ respectively. The findings differed amongst the provinces and between the herd sizes. For majority of the questions the differences amongst the provinces were found to be significant at $\mathrm{p}<0.05$. However, the statistical associations between the herd size were not statistically significant at, $\mathrm{p}<0.05$. The study concluded that the producers in general, applied well-known methods for treatment and control of mastitis, but had lack in knowledge related to basic rules of hygiene applications and disease preventions. These problems are likely to have strong links with the level of formal education and job training of the producers. These findings emphasise that improvements in education and job training of the dairy farmers are as important as the efforts to improve farm size during the process of Turkey's integration to the European Union.
\end{abstract}

Key words: Dairy farming, mastitis control, milk hygiene, producers' profiles, production characteristics

\section{Türkiye'de Konya, Burdur ve Kırklareli İl’lerindeki süt sığırcılık işletmelerinde üretici ve üretim özellikleri ile mastitis kontrol uygulamaları}

Özet: Türkiye'deki süt sığırcılığı işletmelerinde, üretim yapısı, hijyen uygulamaları ve mastitis kontrol faaliyetlerini incelemek amacıyla, Temmuz 2004 tarihinde Burdur, Kırklareli ve Konya illerinde Damızlık Sığır Yetiştiriciliği Merkez Birliği'ne bağlı 91 adet süt sığırcılı̆̆ işletmesine anket uygulanmıştır. Anket çalışmasında, işletme sahiplerinin \% 21 'inin lise ve üzeri bir eğitime sahip olduğu, \% 79'unun süt sığırcılığı ile ilgili herhangi bir eğitim almadığı, \% 46'sının hiçbir şekilde yenilikleri takip etmedikleri, \%93-97'inin işletmeleri açısından en önemli problem olarak düşünülen subklinik mastitis ve somatik hücre sayısı, \% 76'sının ise işletmelerinin geleceği açısından önemli bir tehdit ve/veya firsat olabilecek "Avrupa Birliği Süt Hijyen Yönetmeliği” hakkında bilgi sahibi olmadıkları belirlenmiştir. Ankete katılan üreticilerin \%13'ü meme temizliğinde su ile birlikte antiseptik de kullandığını ve memeleri yıkayan üreticilerin \%37'si yıkamadan sonra memeyi kuruladığını beyan etmiştir. Sağım sonrası teat-dip, kuru dönem sağıtım, mastitis aşısı, Kaliforniya Mastitis Testi uygulayan ve klinik mastitis vakalarını düzenli olarak kaydeden üretici oranları sırasıyla $\% 18, \% 62, \% 29, \% 15$ ve \%20 olarak tespit edilmiştir. Araştırma sonuçları, üreticilerin genelde iyi bilinen mastitis tedavi ve kontrol tekniklerini uyguladıkları halde, hastalıktan korunmaya yönelik hijyen ve hastalık takibi konularında yetersiz olduklarını göstermektedir. Elde edilen bulgular iller ve işletme ölçekleri açısından farklılık göstermesine rağmen, bu farklılıklar istatistikî açıdan değerlendirildiğinde genelde iller arasında önemli, işletme ölçekleri arasında ise önemsiz olarak tespit edilmiştir. Söz konusu problemlerin üreticilerin resmi ve süt sığırcılığına ilişkin teknik eğitim yetersizliğinden kaynaklandığı düşünülmektedir. $\mathrm{Bu}$ durum sektörün $\mathrm{AB}$ 'ne entegrasyonda üreticilerin formal eğitim ve teknik bilgi seviyelerinde sağlanacak olumlu gelişmelerin, en az işletme ölçeklerinin büyütülmesi çabaları kadar önemli olduğunu göstermektedir.

Anahtar sözcükler: Süt sığırcılı̆̆ı, mastitis kontrol, sağım hijyeni, üretici profili, üretim özellikleri.

\footnotetext{
* The paper is a part of the project titled "Incidence of Endemic Diseases and Their Financial Costs in Dairy Herds of The Turkish Dairy Breeding Associations” supported by Ankara University, TURKEY (Project No: 200308 10 050)
} 


\section{Introduction}

The main problems faced by the Turkish dairy farmers are lower level of productivity \& profitability, lack of specialisation, cooperation (4), and high level of endemic diseases and fertility problems $(7,16,17)$. These problems have strong links with producer characteristics, farming systems and hygiene \& disease control applications at dairy herds from one agricultural region to another.

There are numbers of studies investigating the producer characteristics and farming systems of Turkish dairy herds in different regions $(1,2,6,9,12)$. However, during the literature review, studies focussed specifically on hygiene applications and mastitis control methods of Turkish dairy herds were not encountered. The above stated studies had limited information about the hygiene applications and mastitis control methods of Turkish dairy herds.

From this point of view, this paper aims at investigating producer profiles, farm structures and farming activities related to production, hygiene and disease control and prevention at dairy herds in Konya, Burdur and Kirklareli provinces, which represent important milk production regions (the Trace, Aegean and the Middle Anatolian Regions) in Turkey.

\section{Materials and Methods}

An interview survey was carried out in randomly selected 91 dairy herds that were a member of the Dairy
Breeding Association (DBA) (30 dairy herds in Konya, 33 in Burdur and 28 in Kirklareli) out of 1684 DBA herds in these provinces in July, 2004. Herds were stratified as either small-scale (less than 11 milking cows) or medium-large scale (more than 10 milking cows).

In order to determine the most suitable statistical tests for this research, firstly, the data were tested if they were normally distributed with the use of KolmogorovSimirnov Test. Since the "n"s were independent, and the data for all the categories were not normally distributed, nonparametric statistical tests were used. For this purpose $3 \times 2$ and $2 \times 2$ Chi-square Test were used to test the overall statistical significance amongst the provinces and between the herd sizes respectively.

The data were analysed by using MS Excel-XP software and the statistical analyses were conducted with SPSS 15.0 statistical package programme.

\section{Results}

The survey findings according to provinces and herd size are presented in Table-1

As can be seen in Table-1, majority of the producers ( $71 \%-87 \%$ ) had only the compulsory education ( 8 years), generally did not have specific training taken related to dairy farming, and $46 \%$ of the producers did not follows renovations related to their business.

The majority of the producers was not aware of the EU regulations related to dairy farming, and thought

Table-1: The survey findings on the producer profiles, production characteristic of the dairy producers

Tablo-1: Süt sığırcılık işletmelerinin üretici profilleri ve üretim özellikleri konusunda elde edilen araştırma bulguları

\begin{tabular}{|c|c|c|c|c|c|c|}
\hline & \multicolumn{3}{|c|}{ Provinces } & \multicolumn{2}{|c|}{ Scale of Herds ${ }^{\&}$} & \multirow[b]{2}{*}{$\begin{array}{c}\text { Overall } \\
\text { Mean } \\
(\mathrm{n}=91)\end{array}$} \\
\hline & $\begin{array}{l}\text { Burdur } \\
(\mathrm{n}=33)\end{array}$ & $\begin{array}{c}\text { Kirklareli } \\
(\mathrm{n}=28)\end{array}$ & $\begin{array}{l}\text { Konya } \\
(\mathrm{n}=30)\end{array}$ & $\begin{array}{l}\text { Small } \\
(\mathrm{n}=52)\end{array}$ & $\begin{array}{c}\text { Medium- } \\
\text { large } \\
(n=39)\end{array}$ & \\
\hline Percentage of herds having less than 11 cows & $57.6^{\mathrm{a}}$ & $64.3^{\mathrm{a}}$ & $50.0^{\mathrm{a}}$ & & & 57.1 \\
\hline $\begin{array}{l}\text { The percentage of farmers mainly generating the income from dairy } \\
\text { business. }\end{array}$ & $75.8^{\mathrm{a}}$ & $50.0^{\mathrm{b}}$ & $31.0^{\mathrm{b}}$ & 49.0 & 59.0 & 53.3 \\
\hline The percentage of farmers selling their milk via cooperatives & $90.9^{\mathrm{a}}$ & $67.9^{\mathrm{b}}$ & $0.0^{c}$ & 55.8 & 51.3 & 53.8 \\
\hline The percentage of farmers always keeping the cow indoor & $3.0^{\mathrm{a}}$ & $60.7^{\mathrm{b}}$ & $34.5^{c}$ & 37.3 & 23.1 & 31.1 \\
\hline The percentage of farmers purchasing the concentrated feeds. & $87.9^{\mathrm{a}}$ & $53.6^{\mathrm{b}}$ & $89.7^{\mathrm{a}}$ & 76.5 & 79.5 & 77.8 \\
\hline The percentage of farmers having other jobs apart from dairying & $100.0^{\mathrm{a}}$ & $96.4^{\mathrm{a}}$ & $83.3^{\mathrm{a}}$ & 96.2 & 89.7 & 93.4 \\
\hline $\begin{array}{l}\text { The percentage of farmers having not higher than compulsory } \\
\text { education ( } 8 \text { years) }\end{array}$ & $87.5^{\mathrm{a}}$ & $71.4^{\mathrm{a}}$ & $75.9^{\mathrm{a}}$ & 80.0 & 76.9 & 78.8 \\
\hline $\begin{array}{l}\text { The percentage of farmers having special job training related to } \\
\text { dairying }\end{array}$ & $15.2^{\mathrm{a}}$ & $21.4^{\mathrm{a}}$ & $26.6^{\mathrm{a}}$ & 25.0 & 15.4 & 20.9 \\
\hline The percentage of farmers do not follow renovations & $57.6^{\mathrm{a}}$ & $25.0^{\mathrm{b}}$ & $53.3^{\mathrm{a}}$ & 48.1 & 43.6 & 46.2 \\
\hline The percentage of farmers being aware of somatic cell counts & $0.0^{\mathrm{a}}$ & $7.1^{\mathrm{a}}$ & - & 2.7 & 4.2 & 3.3 \\
\hline The percentage of farmers being aware subclinical mastitis & $12.1^{\mathrm{a}}$ & $0.0^{\mathrm{a}}$ & - & 5.4 & 8.3 & 6.6 \\
\hline $\begin{array}{l}\text { The percentage of farmers being aware of the EU's Milk Hygiene } \\
\text { Regulations }\end{array}$ & $33.3^{\mathrm{a}}$ & $25^{\mathrm{a}}$ & $13.3^{\mathrm{a}}$ & 23.1 & 25.6 & 24.2 \\
\hline $\begin{array}{l}\text { The percentage of farmers thought that Turkey's integration to the } \\
\text { AB had positive impacts on their business }\end{array}$ & $15.2^{\mathrm{a}}$ & $39.3^{\mathrm{a}}$ & $36.7^{\mathrm{a}}$ & 26.9 & 33.3 & 29.7 \\
\hline
\end{tabular}

${ }^{\&}$ Herds having less than 11 milking cows are grouped as small scale $*$ : significant at $\mathrm{p}<0.05$.

$a, b, c$ : Different letter in the same row refers statistically significant association at $p<0.05$. 
Table-2: The survey findings on the hygiene applications of the dairy producers

Tablo-2: Süt sığırcılık işletmelerinin hijyen uygulamalarına ilişkin araştırma bulguları

\begin{tabular}{|c|c|c|c|c|c|c|}
\hline & \multicolumn{3}{|c|}{ Provinces } & \multicolumn{2}{|c|}{ Scale of Herds ${ }^{\&}$} & \multirow[b]{2}{*}{$\begin{array}{c}\text { Overall } \\
\text { Mean } \\
(\mathrm{n}=91)\end{array}$} \\
\hline & $\begin{array}{l}\text { Burdur } \\
(\mathrm{n}=33)\end{array}$ & $\begin{array}{l}\text { Kirklareli } \\
(\mathrm{n}=28)\end{array}$ & $\begin{array}{l}\text { Konya } \\
(\mathrm{n}=30)\end{array}$ & $\begin{array}{l}\text { Small } \\
(\mathrm{n}=52)\end{array}$ & $\begin{array}{c}\text { Medium- } \\
\text { large } \\
(\mathrm{n}=39)\end{array}$ & \\
\hline The percentage of farmers having byre milking system & $90.9^{\mathrm{a}}$ & $96.4^{\mathrm{a}}$ & $93.3^{\mathrm{a}}$ & $98.1 *$ & $87.2 *$ & 93.4 \\
\hline $\begin{array}{l}\text { The percentage of herd in which the same person is in charge of } \\
\text { milking }\end{array}$ & $78.8^{\mathrm{a}}$ & $89.3^{\mathrm{a}}$ & $93.3^{\mathrm{a}}$ & 86.5 & 87.2 & 86.6 \\
\hline The percentage of milkers regularly using gloves during milking & $33.3^{\mathrm{a}}$ & $0.0^{\mathrm{b}}$ & $20.0^{c}$ & 15.9 & 22.2 & 18.3 \\
\hline $\begin{array}{l}\text { The percentage of milkers regularly clean their hands with } \\
\text { disinfectant }\end{array}$ & $6.1^{\mathrm{a}}$ & $0.0^{\mathrm{a}}$ & $13.3^{\mathrm{a}}$ & 7.7 & 5.1 & 6.6 \\
\hline The percentage of farmers feeding the cows during milking & $100.0^{\mathrm{a}}$ & $100.0^{\mathrm{a}}$ & $80.0^{\mathrm{b}}$ & 98.1 & 87.2 & 85.0 \\
\hline The percentage of farmers correctly ordered cows during milking & $36.4^{\mathrm{a}}$ & $89.3^{\mathrm{b}}$ & $3.4^{c}$ & 38.5 & 47.4 & 42.2 \\
\hline The percentage of farmers having special cubicle for sick cattle & $21.2^{\mathrm{a}}$ & $3.6^{\mathrm{b}}$ & $30.0^{\mathrm{a}}$ & 15.4 & 23.1 & 18.7 \\
\hline $\begin{array}{l}\text { The percentage of farmers cleaning heads of the machine before } \\
\text { using for the next cow }\end{array}$ & $9.1^{\mathrm{a}}$ & $39.3^{\mathrm{b}}$ & $46.7^{\mathrm{b}}$ & 26.9 & 35.9 & 30.8 \\
\hline $\begin{array}{l}\text { The percentage of farmers properly cleaning milking machine after } \\
\text { milking }\end{array}$ & $30.3^{\mathrm{a}}$ & $42.9^{\mathrm{a}}$ & $40.0^{\mathrm{a}}$ & 42.3 & 30.8 & 37.4 \\
\hline The percentage of farmers given colostrums to all calves & $100.0^{\mathrm{a}}$ & $100.0^{\mathrm{a}}$ & $86.7^{\mathrm{b}}$ & 98.1 & 87.2 & 93.4 \\
\hline
\end{tabular}

${ }^{\&}$ Herds having less than 11 milking cows are grouped as small scale $*$ : significant at $\mathrm{p}<0,05$.

a,b,c : Different letter in the same row refers statistically significant association at $\mathrm{p}<0,05$.

Table-3: The survey findings on the mastitis control methods used by the dairy producers

Tablo-3: Süt sığırcılık işletmelerinde uygulanan mastitis kontrol metotlarına ilişkin elde edilen araştırma bulguları

\begin{tabular}{|c|c|c|c|c|c|c|}
\hline & \multirow[b]{2}{*}{$\begin{array}{l}\text { Burdur } \\
(\mathrm{n}=33)\end{array}$} & \multicolumn{2}{|l|}{ Provinces } & \multicolumn{2}{|c|}{ Scale of Herds ${ }^{\&}$} & \multirow{2}{*}{$\begin{array}{c} \\
\text { Overall } \\
\text { Mean } \\
(\mathrm{n}=91)\end{array}$} \\
\hline & & $\begin{array}{l}\text { Kirklareli } \\
(\mathrm{n}=28)\end{array}$ & $\begin{array}{l}\text { Konya } \\
(\mathrm{n}=30)\end{array}$ & $\begin{array}{l}\text { Small } \\
(\mathrm{n}=52)\end{array}$ & $\begin{array}{l}\text { Medium- } \\
\text { large } \\
(\mathrm{n}=39)\end{array}$ & \\
\hline $\begin{array}{l}\text { The percentage of farmers treating clinical mastitis cases by } \\
\text { himself/herself }\end{array}$ & $63.6^{\mathrm{a}}$ & $46.4^{\mathrm{a}}$ & $60.0^{\mathrm{a}}$ & 53.8 & 61.5 & 57.1 \\
\hline $\begin{array}{l}\text { The percentage of farmers cleaning the udders with water and } \\
\text { antiseptic }\end{array}$ & $6.1^{\mathrm{a}}$ & $10.7^{\mathrm{a}}$ & $23.1^{\mathrm{a}}$ & 8.0 & 18.9 & 12.6 \\
\hline The percentage of farmers regularly drying udder after washing & $39.4^{\mathrm{a}}$ & $25.0^{\mathrm{a}}$ & $45.5^{\mathrm{a}}$ & 32.7 & 41.2 & 36.1 \\
\hline The percentage of farmers applying teat dipping after milking & $21.2^{\mathrm{a}}$ & $10.7^{\mathrm{a}}$ & $23.1^{\mathrm{a}}$ & 18.0 & 18.9 & 18.4 \\
\hline The percentage of the producers applying dry cow therapy & $54.5^{\mathrm{a}}$ & $78.6^{\mathrm{a}}$ & $53.3^{\mathrm{a}}$ & 63.5 & 59.0 & 61.5 \\
\hline The percentage of farmers using vaccine against mastitis & $27.3^{\mathrm{b}}$ & $42.9^{\mathrm{a}}$ & $16.7^{\mathrm{b}}$ & 28.8 & 28.1 & 28.6 \\
\hline $\begin{array}{l}\text { The percentage of farmers regularly keeping records for clinical } \\
\text { mastitis }\end{array}$ & $12.1^{\mathrm{a}}$ & $25.0^{\mathrm{a}}$ & $23.3^{\mathrm{a}}$ & 15.4 & 25.6 & 19.8 \\
\hline The percentage of farmers regularly applying CMT Test & $0.0^{\mathrm{a}}$ & $7.1^{\mathrm{a}}$ & $6.7^{\mathrm{a}}$ & 3.8 & 5.1 & 4.4 \\
\hline $\begin{array}{l}\text { The percentage of farmers whose milking machine had vacuum } \\
\text { regulator }\end{array}$ & $100.0^{\mathrm{a}}$ & $81.0^{\mathrm{b}}$ & $93.1^{b}$ & 95.3 & 91.9 & 92.8 \\
\hline $\begin{array}{l}\text { The percentage of farmers changing rubbers of the milking machine } \\
\text { less the } 1 \text { year }\end{array}$ & $63.3^{\mathrm{a}}$ & $46.2^{\mathrm{a}}$ & $26.9^{\mathrm{b}}$ & 52.2 & 38.9 & 46.3 \\
\hline $\begin{array}{l}\text { The percentage of farmers having the problem of "slipping the head } \\
\text { of milking machine from udders during milking" }\end{array}$ & $71.7^{\mathrm{a}}$ & $35.7^{\mathrm{b}}$ & $40.0^{\mathrm{b}}$ & 46.2 & 56.4 & 50.5 \\
\hline $\begin{array}{l}\text { The percentage of farmers always rearing their replacement heifer in } \\
\text { farm }\end{array}$ & $100.0^{\mathrm{a}}$ & $71.4^{\mathrm{b}}$ & $73.3^{\mathrm{b}}$ & 84.6 & 79.5 & 82.4 \\
\hline
\end{tabular}

${ }^{\&}$ Herds having less than 11 milking cows are grouped as small scale *: significant at $\mathrm{p}<0.05$.

a,b,c : Different letter in the same row refers statistically significant association at $\mathrm{p}<0.05$. 
Turkey's integration to the EU would negatively affect their business.

The study depicted that the producers in general, applied well-known methods for treatment and control of mastitis, but had lack in knowledge related to basic rules of hygiene applications and disease preventions (Table 2 and 3).

Despite the fact that the survey findings were differs according to the provinces, for majority of the questions these differences were not found to be statistically significant at $p<0.05$. However, the statistical associations of the differences amongst the provinces in questions of "the percentage of farmers selling their product via cooperatives, always keeping their cows indoor, their milkers regularly use of gloves and correct ordering of cows during milking" were found to be significant at $\mathrm{p}<0.05$.

For some questions, the figures in one province were found to be statistically significant from the others. For instance, dairy businesses were the main source of income for the majority (76\%) of the producers in Burdur. None of the producers in Konya sold their milk through cooperatives. Most of the producers in Kirklareli kept the cattle in-door. Unlike the other provinces, almost half of the producers in Kurklareli produced their concentrated feed at farm. Moreover, percentage of farmers following renovation, and as linked with this use of vaccine for mastitis, and correct ordering of cows during milking were higher in this province.

Apart from the questions "percentage of farmers having byre milking system", the statistical association of the differences between the herd sizes were not found to be significant at $\mathrm{p}<0.05$.

\section{Discussion and Conclusion}

In spite of the fact that the DBA herds were much better than an average national dairy herd in terms of size, amount of investment made and market orientation, the survey results depicted that owners/producers of these herds had insufficient level of formal education as well as job training (on production, hygiene and disease control).

The figures for the formal education level of the modern egg producers/owners in Turkey were reported to be much higher than those of modern dairy producers reported in here $(8,11)$. An average length of formal education reported in this study was 7.2 years. The similar studies conducted in Turkey reported even a lower figure for the level of education. For instance, the average length of formal education of dairy farmers in Tokat and Kayseri provinces were reported to be 6.3 and 5.9 years respectively $(6,10)$. On the other hand, Sahin et al. (9) reported that $86 \%$ of the dairy producers in Adana province were only primary school graduates. Yıldız
(18), reported this figure slightly higher (7.6 years) in Ankara province.

Reported figures related to the formal education level and job training in other countries were much higher than those of Turkish dairy farmers. For instance, Urassa and Raphael (14) reported that only $8 \%$ of the dairy producers were primary school graduates, and 30\% of them had a university degree in Tanzania. In the same study, the percentage of farmers having special training for dairy farming was reported to be $62 \%$. Flaten et al. (3) reported that $40 \%$ of the dairy farmers had a university degree and $76 \%$ of them had specific job training in Norway. Similarly, Wolf (15) reported that the percentage of producers having less than 12 years formal education was $1.6 \%$, and $52 \%$ of the producers had a university degree (17\% had a postgraduate degree) in the United States. The above comparisons clearly indicate that the level of formal education and job training of Turkish dairy producers are too low compared to those in other developed and developing countries in the world, and it may be considered as the main reasons of the other problems (e.g. low productivity and profitability, high level of disease incidences) they faced.

In this study, the percentage of producers never following renovations related to their business was $46 \%$. For those, following the renovations, the main source was the printed material only. Yildiz (18) reported the figure as $27 \%$. However, he stated that the main source was the printed material only (particularly the 3-montly journal of Turkish Dairy Breeding Association).

If Turkey becomes a member of the EU, the Turkish dairy producers will face with severe sanctions to be fulfilled in terms of milk hygiene (maximum accepted levels of somatic cell count, total bacterial counts, antibiotic residue etc.) These milk hygiene regulations might force some of the producers to quit their business. However, the majorities of the producers were not aware of the EU regulations related to dairy farming, and had no idea about the likely impact of Turkey's integration to the EU on the Turkish dairy sector and their business. This is again a reflection of lack of education and ability to follow treats \& opportunities they were encountered with.

The scale of dairy enterprise in Turkey, including the herds involved in this research, is too small to generate sufficient income for dairy farmers and their families, so the majority of the producers have another farming activity and/or off-farm jobs. This hampers the specialisations in the business and they, therefore, cannot utilise the advantages of scale economies in dairy operation. Dairy farming in the developed countries is much more specialised. For example, Wolf (15) reported that $47.3 \%$ of the dairy producers were not engaged in any other farming and off-farm activities besides dairy business in the US. 
Provision of feed, particularly fodder, from their own farm source has a great impact on lowering production costs in dairy herds. The fact that, the percentage of fodder crop in the total planted area in the provinces $(26 \%-30 \%)$ is much higher than that of national average $(6 \%)$, and those reported in other studies in Turkey $(9,10,12,13)$ indicate that the producers are well aware of the importance of this issue. Furthermore, the climate in Kurklareli allows plantation of maize as a second crop after harvesting the main crop (generally sun flower), which gives the producers a great advantage of lowering the feed cost.

During the field visits, it was observed that the producers in general consider vets as a fire brigade. They generally call vets when the prognosis of a disease is severe. They hardly had a contract with vets to design a planned disease control \& prevention programmes. This may explain why the producers generally apply wellknown methods for treatment and control of diseases, but lack in knowledge related to basic rules of hygiene and preventions from diseases. For example, the producers were generally aware of the applications of vaccination against mastitis, dry cow therapy, but they were hardly aware of sub clinical mastitis and its relation to clinical cases, importance of good milking practices (regular check of milking machine, use of glows while milking, cleaning hands before milking, use of post milking teat dip, etc.) and observation of diseases (regular recording of clinical mastitis cases and tracing sub-clinical cases with CMT test).

The findings of the other studies conducted in different provinces of Turkey $(1,6)$ were similar, even worse. For instance, percentages of herds where milking is practiced by hand in Tokat (in Black Sea Region, Turkey), Van and Kars (in East Anatolian Region, Turkey) were $80 \%, 95 \%$ and $80 \%$ respectively $(1,2,6)$.

In developed countries, almost all dairy producers apply basic hygiene and disease control and prevention methods. For instance, according to the survey results conducted in Scotland in 1993 (16), 84\% of the dairy herds had a parlour system. The percentages of producers using udder preparation (UP), post milking teat dipping (PMTD), dry cow therapy (DCT) and regular servicing of milking machine were reported to be $76 \%, 80 \%, 97 \%$ and $83 \%$ respectively. The rates for UP, PMTD and regular servicing of milking machine increased to $90 \%$, $88 \%$ and $97 \%$ respectively in Scotland in 1996 (5). These findings indicate the difference in the rates of hygiene and mastitis control applications preferred in Turkey and in other developed countries.

In conclusion, the findings of this study, besides those of the other studies conducted in Turkey, demonstrate that lack of education and job training seem to be the main problems in dairy herds in Turkey.
Problems related to hygiene and disease control and preventions are likely to have strong links with education level of farmers. These findings emphasise that efforts to educate and train dairy farmers are as important as efforts to improve farm size during the process of Turkey's integration to the European Union.

\section{Acknowledgements}

This project (Project No: 20030810 050) was funded by Scientific Research Funds. We thank to the Turkish Dairy Breeding Association for their collaborations.

\section{References}

1. Bakır G (2002): Van İlindeki özel süt sığırcıllı̆̆ işletmelerinin yapısal durumu. Y.Y. Ü.Zir. Fak. Tarım Bilim. Derg., 12, 1-10.

2. Erdoğan HM, Çitil M, Güneş V (2004): Dairy cattle farming in Kars district, Turkey: I. characteristics and production. Turk J Vet Anim Sci, 28, 735-743.

3. Flaten O, Lien G, Ebbesvik M, Koesling M, Vale PS (2004): XI. World congress of rural sociology, Trondheim, Norway. "www.norsok.no/publikasjoner/flaten IRSA\%20 me04.pdf”. Accessed May 2005.

4. Günlü A (1997): Konya Ili Süt Siğırcılık Ișletmelerinde Karlilık ve Verimlilik Analizleri ile Işletmelerin Üretim ve Pazarlama Sorunları. Ankara Üniversitesi Sağlık Bilimleri Enstitüsü. Doktora Tezi. Ankara.

5. Gunn J, Chaplin SE, Yalçın C, Ternent HE, Offer JE, Stott AW, Logue DN (1997): Report on the milk levy disbursement fund contract 619/93/13 SAC publication, 143 p. Edinburgh. 1997.

6. Karaaslan G (2000): Tokat Ili Merkez Ilçede Projeye Dayalı Damızlık Süt Siğırcılığ Işletmelerinin Ekonomik Analizi. Gazi Osman Paşa Üniversitesi Fen Bilimleri Enstitüsü. Yüksek Lisans Tezi. Tokat.

7. Kumuk T, Akbaş Y, Türkmut L (1999): Süt sı̆̆ırcılı̆̆ında döl verimine ilişkin ekonomik kayıplar ve yetiştiricilerin bilgi ve teknoloji ihtiyact. Uluslararası Hayvancilık'99 Kongresi. İzmir, 59-64.

8. Sarıözkan S (2005): Afyon İli Yumurta Tavukçuluğu İsletmelerinde Karlılık ve Verimlilik Analizleri. Ankara Üniversitesi Sağlık Bilimleri Enstitüsü Müdürlüğü. Doktora Tezi. Ankara.

9. Şahin K, Gül A, Koç B, Dağıstan E (2001): Adana Illinde entansif süt slğırcllı̆̆ üretim ekonomisi. Y.Y. Ü.Zir. Fak. Tarım Bilim. Derg., 11, 19-28.

10. Şahin K (2001): Kayseri İlinde süt siğırcıll̆ğ yapan işletmelerin yapısal özellikleri ve pazarlama sorunlart. Y.Y. Ü.Zir. Fak. Tarım Bilim. Derg., 11, 79-86.

11. Tuğluk E, Yalçın C (2004): Nevşehir Ili Kozaklı Ilçesinde yumurta tavukçuluğu işletmelerinin genel yapisal özellikleri ve karşılaşılan sorunlar. Tavukçuluk Araştırma Enstitüsü Dergisi, 5, 41-46.

12. Turan A (1997): Çerkeş İlçesinde süt sı̆̆ırcılı̆̆ yapan tarım işletmeleri üzerine kooperatifleşmenin etkileri. Türk Kooperatifçilik Eğitim Vakfı Yayınları. No: 5. Ankara.

13. TURKSTAT (2002): Tarımsal Yap1 (Üretim, Fiyat, Değer), Ankara. 
14. Urassa JK, Raphael E (2004): The contribution of small scale dairy farming to community welfare: a case study of Morogoro Municipality. Electronic publications from Sokoine University of Agriculture, Morogoro, Tanzania.; http://www.fiuc.org/iaup/sap/ Accessed May 2005.

15. Wolf C (2002): Custom dairy heifer growing: summary and analysis of a 2001 grower survey. Michigan State University Agricultural Economics Report. No: 615, USA.

16. Yalçın C, Sarı̈̈zkan S, Yıldız AŞ, Günlü A (2008): Incidence of endemic diseases in Turkish dairy herds. Turk J Vet Anim Sci 32: 423-428.

17. Yalçın C (1996): The Economic Impact of Mastitis Control Procedures in Scottish Dairy Herds. PhD thesis. Aberdeen University, United Kingdom.
18. Yıldız, AŞ (2008): Ankara Damızlık Sı̆̆ır Yetiştiricileri Birliği'ne Bağll Süt Sı̆̆ırcıllı̆g İşletmelerinde Bazı Endemik Hastalıkların İşletme Düzeyinde Meydana Getirdiği Ekonomik Kayıplar. Ankara Üniversitesi Sağlık Bilimleri Enstitüsü. Doktora tezi. Ankara.

Geliş tarihi: 01.08.2008 / Kabul tarihi: 09.01.2009

\section{Address for correspondence:}

Prof. Dr. Cengiz Yalçın

Department of Animal Health Economics and Management, Faculty of Veterinary Medicine,

Ankara University,

06110 Dışkapı, Ankara, Turkey

e-mail:cyalcin@veterinary.ankara.edu.tr 